\title{
PENGANTAR DAN LANGKAH-LANGKAH PROSES KEPERAWATAN \\ DI RUMAH SAKIT
}

\author{
Esty Purnama Sari
}

Estypurnamasari97@gmail.com

\section{Latar Belakang}

Proses keperawatan merupakan suatu jawaban untuk pemecahan masalah dalam keperawatan, karena proses keperawatan merupakan metode ilmiah yang digunakan secara sistematis dan menggunakan konsep dan prinsip ilmiah dalam mencapai diagnosa masalah kesehatan pasien, merumuskan tujuan yang ingin dicapai, menentukan tindakan dan mengevaluasi mutu serta hasil asuhan keperawatan. Dalam pratiknya perawat menggunakan pengetahuannya tentang proses keperawatan untuk mengkaji kesehatan klien, menegakkan diagnosa, merencakan asuhan keperawatan, menerapkan dan mengevaluasi tindakan keperawatan yang diberikan. Perawat diharapkan memahami tentang konsep proses keperawatan dan mampu menerapkan serta menyusunannya dalam sebuah dokumen status kesehatan klien (Rohmah, N dan Walid, S. 2009).

Inti dari dokumentasi adalah proses keperawatan. Sehingga kualitas dokumentasi keperawatan merupakan cermin dari keberhasilan asuhan dalam proses keperawatan (Jan Florin 2007). Pendokumentasian yang tidak dilakukan dengan lengkap dapat menurunkan mutu pelayanan keperawatan karena tidak dapat mengidentifikasi sejauh mana tingkat keberhasilan asuhan keperawatan yang telah diberikan, dalam aspek legal perawat tidak mempunyai bukti tertulis jika klien menuntut ketidakpuasan akan pelayanan keperawatan (Nursalam, 2008; Iyer, 2001).

Dokumentasi asuhan keperawatan menggunakan pendekatan proses keperawatan yang terdiri dari 5 langkah yaitu : pengkajian, perumusan diagnosa, perencanaan, pelaksanaan, dan evaluasi sebagai metode ilmiah penyelesaian masalah keperawatan pada pasien untuk meningkatkan outcome pasien (Aziz, 2002). Ciri dokumentasi asuhan keperawatan yang baik adalah berdasarkan fakta (factual basis), akurat (accuracy), lengkap (completeness), ringkas 
(conciseness), terorganisir (organization), waktu yang tepat (time liness), dan bersifat mudah dibaca (legability) (Potter \& Perry; 2009). Prinsip-prinsip pendokumentasian direvisi menjadi tiga bentuk standar dokumentasi yaitu communication, accountability, dan safety (ANA, 2010).

Kata Kunci : Proses Keperawatan, Pengantar, Langkah-langkah Proses Kepeawatan

\section{Metode}

Metode yang digunakan yaitu literature review, yaitu dengan menganalisis buku-buku dan jurnal online yang berkaitan dengan pengantar dan langkah-langkah proses keperawatan di rumah sakit. Dalam Penulisan Jurnal ini diawali dengan pemilihan topik, kemudian menuliskan kata kunci "Proses Keperawatan”, "Pengantar” dan “ Langkah-langkah Proses Keperawatan”. Dari hasil pencarian jurnal online kemudian diolah dan dianalisis sehingga menghasilkan sebuah pembahasan dan kesimpulan dari topik yang ditetapkan. Sumber penelitian ini berasal dari beberapa literature jurnal. Jurnal ini dibatasi dengan tahun paling tua 2012. Jumlah referensi jurnal yang digunakan sebanyak 12 referensi jurnal. Berdasarkan tujuan penelitian, maka penelitian ini merupakan penelitian eksplorasi untuk mengetahui mengenai proses keperawatan dan langkah-langkah proses keperawatan di rumah sakit yang dapat dilihat dari referensi.

\section{Hasil}

Gambaran pendokumentasian asuhan keperawatan oleh perawat pelaksana di Rumah Sakit Umum Daerah Ambarawa, Hasil penelitian menunjukkan pendokumentasi belum dapat mencapai angka yang optimal, karena belum adanya upaya evaluasi kinerja dalam pendokumentasian yang dilakukan oleh perawat, sehingga faktor tingkat pendidikan dan masa kerja juga tidak memiliki dampak yang signifikan terhadap kelengkapan dokumetasi asuhan.

Hal ini sejalan dengan penelitian Sugiharti (2012) bahwa kelengkapan hasil dokumentasi asuhan keperawatan di rumah sakit belum dapat mencapai 80\%. Hasil penelitian pada pendokumentasian yang belum mencapai 80\%, hal ini disebabkan karena kelengkapan 
dokumentasi bukan hanya dipengaruhi oleh faktor pengetahuan perawat, tetapi beban kerja perawat dan ketersediaan waktu juga dapat mempengaruhi kelengkapan dokumentasi.

Dan juga sejalan dengan penelitian pelaksanaan dokumentasi keperawatan di Rumah Sakit Islam Kendal rata - rata baik. Pada pelaksanaan dokumentasi keperawatan di Rumah Sakit Islam Kendal diperoleh nilai baik ada 24 orang $(80 \%)$.

Pelayanan keperawatan yang bermutu harus memenuhi karakteristik proses keperawatan dengan sistem terbuka, fleksibel terhadap kebutuhan pasien dan dinamis, berpusat pada pasien, terencana, mempunyai tujuan dan ada umpan balik. Dokumentasi keperawatan penting karena mampu merekam kronologis kondisi pasien, mencatat semua tindakan yang dilakukan dan respon pasien terhadap perawatan. Penulisan dokumentasi keperawatan tidak mengacu pada standar yang sudah ditetapkan, sehingga terkadang tidak lengkap dan akurat. Hal ini sesuai dengan pendapat Fiscbach (2011), bahwa banyak faktor yang merupakan hambatan dalam melaksanakan dokumentasi keperawatan, meskipun pada dasarnya proses keperawatan telah diterapkan.

\section{Pembahasan}

1. Pengantar Proses Keperawatan

Proses keperawatan merupakan metode ilmiah yang dipakai dalam memberikan asuhan keperawatan yang profesional. Perawat, dimana saja ia bertugas, menghadapi klien dengan segala macam kasus, dan melayani klien pada semua tingkat usia juga harus menggunakan proses keperawatan. Perawat diharapkan memahami tentang konsep proses keperawatan dan mampu menerapkan serta menyusunannya dalam sebuah dokumen status kesehatan klien (Rohmah, N dan Walid, S. 2009).

Proses keperawatan adalah aktivitas yang mempunyai maksud yaitu praktik keperawatan yang dilakukan dengan cara yang sistematik. Selama melaksanakan proses keperawatan, perawat menggunakan dasar pengetahuan yang komprehensif untuk mengkaji status kesehatan klien, membuat penilaian yang bijaksana dan mendiagnosa, mengidentifikasi hasil akhir kesehatan 
klien dan merencanakan, menerapkan dan mengevaluasi tindakan keperawatan yang tepat guna mencapai hasil akhir tersebut (Dermawan, 2012).

Hubungan perawat klien adalah dasar dari praktik keperawatan yang berfokus pada pasien (patient centered care). Keterlibatan pasien merupakan inti dari proses keperawatan, sehingga partisipasi pasien dalam proses keperawatan menjadi penting dalam penentuan kualitas dan efektifitas dalam pelayanan asuhan keperawatan. Inti dari dokumentasi adalah proses keperawatan. Sehingga kualitas dokumentasi keperawatan merupakan cermin dari keberhasilan asuhan dalam proses keperawatan (Jan Florin 2007). Mutu asuhan keperawatan dapat tergambar dari dokumentasi proses keperawatan (Gillies, 1994).

Pendokumentasian merupakan suatu kegiatan pencatatan, pelaporan atau merekam suatu kejadian serta aktivitas yang dilakukan dalam bentuk pemberian pelayanan yang dianggap penting dan berharga (Dalami, 2011). Pendokumentasian yang tidak dilakukan dengan lengkap dapat menurunkan mutu pelayanan keperawatan karena tidak dapat mengidentifikasi sejauh mana tingkat keberhasilan asuhan keperawatan yang telah diberikan, dalam aspek legal perawat tidak mempunyai bukti tertulis jika klien menuntut ketidakpuasan akan pelayanan keperawatan (Nursalam, 2008; Iyer, 2001). Dokumentasi proses asuhan keperawatan yang baik dan berkualitas haruslah akurat, lengkap dan sesuai standar. Apabila kegiatan keperawatan tidak didokumentasikan dengan akurat dan lengkap maka sulit untuk membuktikan bahwa tindakan keperawatan telah dilakukan dengan benar (Pancaningrum D, 2015).

\section{Langkah-Langkah Proses Keperawatan}

Dokumentasi asuhan keperawatan menggunakan pendekatan proses keperawatan yang terdiri dari 5 langkah yaitu: pengkajian, perumusan diagnosa, perencanaan, pelaksanaan, dan evaluasi sebagai metode ilmiah penyelesaian masalah keperawatan pada pasien untuk meningkatkan outcome pasien (Aziz, 2002). Salah satu manfaat dari penerapan asuhan keperawatan yang baik adalah meningkatkan mutu dan kualitas pelayanan dalam bidang keperawatan (Kozier, 2010). 


\section{a. Pengkajian}

Menurut Potter dan Perry, 2005, p.144 mengatakan bahwa pengkajian merupakan proses sistematis dari pengumpulan, verifikasi dan komunikasi tentang pasien. Dimana tujuan pengkajian adalah mendapatkan data dasar tentang kebutuhan, masalah kesehatan, pengalaman yang berkaitan, praktik kesehatan, tujuan, nilai dan gaya hidup yang dilakukan pasien. Kriteria pengkajian keperawatan meliputi: pertama pengumpulan data dilakukan dengan cara anamnesa, observasi, pemeriksaan fisik, serta pemeriksaan penunjang. Kedua, sumber data adalah pasien, keluarga atau orang yang terkait, tim kesehatan, rekam medik, dan catatan lain masa lalu, status kesehatan pasien saat ini, status bio, psiko, sosial spiritual, respon terhadap terapi. Harapan terhadap tingkat kesehatan yang optimal, resiko-resiko tinggi terhadap masalah. Kegiatan utama yang dilakukan dalam tahap pengkajian ini antara lain pengumpulan data, pengelompokan data, menganalisis data guna merumuskan diagnosis keperawatan.

\section{b. Diagnosa}

Diagnosis Keperawatan merupakan keputusan klinik tentang respon individu, keluarga dan masyarakat tentang masalah kesehatan aktual atau potensial, dimana berdasarkan pendidikan dan pengalamannya, perawat secara akuntabilitas dapat mengidentifikasi dan memberikan intervensi secara pasti untuk menjaga, menurunkan, membatasi, mencegah dan merubah status kesehatan klien (Yeni, 2008). Untuk dapat merumuskan diagnosa keperawatan dibutuhkan kemampuan analisis yang tinggi sehingga diperlukan sumber daya manusia yang capable dan mempunyai motivasi kuat untuk maju serta berpandangan maju (futuristic). (Potter dan Perry, 2005, p.166) berpendapat bahwa proses diagnostik mencakup analisis kritis dan interpretasi data, identifikasi masalah klien dan perumusan diagnosa keperawatan.

\section{c. Perencanaan / Intervensi}

Perencanaan merupakan tahap selanjutnya setelah pengkajian dan penentuan diagnosa keperawatan. Jika diagnosa berubah maka intervensi harus mengikuti diagnosa yang muncul dan terdokumentasi. Perencanaan juga merupakan petunjuk tertulis yang menggambarkan secara tepat mengenai rencana tindakan yang dilakukan terhadap pasien sesuai dengan tingkat kebutuhan berdasarkan diagnosa keperawatan yang muncul. Untuk itu rencana tindakan yang baik tentunya harus berdasarkan pada diagnosa keperawatan yang telah dirumuskan (Hartati, 
Handoyo, Anis, 2010). Tahap perencanaan merupakan suatu proses penyusunan berbagai intervensi keperawatan yang dibutuhkan untuk mencegah, menurunkan atau mengurangi masalah-masalah klien.

Dalam menentukan tahap perencanaan bagi perawat diperlukan berbagai pengetahuan dan keterampilan diantaranya pengetahuan tentang kekuatan dan kelemahan klien, nilai dan kepercayaan klien, batasan praktek keperawatan, peran dari tenaga kesehatan lainnya, kemampuan dalam memecahkan masalah, mengambil keputusan, menulis tujuan serta memilih dan membuat strategi keperawatan yang aman dalam memenuhi tujuan, menulis instruksi keperawatan serta kemampuan dalam melaksanakan kerja sama dengan tingkat kesehatan lain. Hal ini didukung oleh Siagian (2002), bahwa semakin tinggi tingkat pendidikan seseorang, maka akan semakin tinggi pengetahuannya.

\section{d. Pelaksanaan / Implementasi}

Implementasi yaitu melakukan dan mendokumentasikan tindakan yang merupakan tindakan keperawatan khusus yang diperlukan untuk melaksanakan intervensi (Kozier, 2010, p.429). Implementasi tindakan keperawatan disesuaikan dengan rencana tindakan keperawatan. Sebelum melaksanakan tindakan yang sudah direncanakan, perawat perlu memvalidasi dengan singkat apakah rencana tindakan masih sesuai dan dibutuhkan klien sesuai dengan kondisinya saat ini. Perawat juga menilai diri sendiri, apakah mempunyai kemampuan interpersonal, intelektual, teknikel, sesuai dengan tindakan yang akan dilaksanakan (Nurjanah S, 2013).

\section{e. Evaluasi}

Tahap evaluasi merupakan tahap terakhir dari proses keperawatan berupa perbandingan yang sistematis dan terencana dari hasil-hasil yang diamati dengan tujuan dan kriteria hasil yang dibuat pada tahap perencanaan. Evaluasi merupakan proses yang berkelanjutan untuk menilai efek dari tindakan keperawatan kepada klien. Evaluasi dilakukan terus menerus pada respon klien terhadap tindakan keperawatan yang dilaksanakan (Kol, Jacobson dan Wieler, 2003). Evaluasi adalah mengkaji respon pasien terhadap tindakan keperawatan yang telah dilakukan oleh perawat dengan mengacu pada standar atau kriteria hasil yang telah ditetapkan pada rumusan tujuan. Terlihat pada status pasien yang telah dikaji bahwa kriteria keherhasilan yang dapat digunakan sebagai dasar evaluasi ini tidak selalu dicantumkan sehingga evaluasi yang 
dilakukan kurang mengacu pada tujuan (Hartati, 2010). Evaluasi dibagi menjadi dua yaitu evaluasi proses atau formatif dilakukan setiap selesai melaksanakan tindakan, evaluasi hasil atau sumatif dilakukan dengan membandingkan respon klien pada tujuan khusus dan tujuan umum yang telah ditentukan (Nurjanah S, 2013).

Apabila hasil menunjukkan ketercapaian tujuan dan kriteria hasil, maka pasien keluar dari siklus

proses keperawatan, namun apabila sebaliknya, maka pasien masuk ke dalam siklus proses keperawatan mulai dari pengkajian ulang (Potter \& Perry, 2005).

\section{Penutup}

Dari berbagai uraian yang telah dijelaskan sebelumnya maka dapat disimpulkan bahwa Proses keperawatan merupakan suatu jawaban untuk pemecahan masalah dalam keperawatan, karena proses keperawatan merupakan metode ilmiah yang digunakan secara sistematis dan menggunakan konsep dan prinsip ilmiah dalam mencapai diagnosa masalah kesehatan pasien, merumuskan tujuan yang ingin dicapai, menentukan tindakan dan mengevaluasi mutu serta hasil asuhan keperawatan. Inti dari dokumentasi adalah proses keperawatan. Sehingga kualitas dokumentasi keperawatan merupakan cermin dari keberhasilan asuhan dalam proses keperawatan (Jan Florin 2007). Dokumentasi asuhan keperawatan menggunakan pendekatan proses keperawatan yang terdiri dari 5 langkah yaitu: pengkajian, perumusan diagnosa, perencanaan, pelaksanaan, dan evaluasi sebagai metode ilmiah penyelesaian masalah keperawatan pada pasien untuk meningkatkan outcome pasien (Aziz, 2002). Salah satu manfaat dari penerapan asuhan keperawatan yang baik adalah meningkatkan mutu dan kualitas pelayanan dalam bidang keperawatan (Kozier, 2010). 


\section{Daftar Pustaka}

1). Astar, F., Hasmin, T., Ikhasan, K. (2015). Pengaruh Pelayanan Asuhan Keperawatan Terhadap Kepuasan Pasien Di Puskesmas Takalala Kabupaten Soppeng. Journal of Management, 1 (2)

2). Damanik, M., Rahmi, F., Leni, M. (2019). Gambaran Keakuratan Dokumentasi Asuhan Keperawatan. Jurnal Kesehatan Andalas, 8(4)

3). Putra, A, A., Sri, R., Tri, N, K. (2016). Hubungan Persepsi Perawat Tentang Karakteristik Pekerjaan Dengan Kepatuhan Dalam Pendokumentasian Asuhan Keperawatan. Jurnal Keperawatan Notokusumo, IV (1).

4). Rahayu, C, D., Sri, M. (2020). Pengambilan Keputusan Klinis Perawat. Jurnal Ilmiah Kesehatan, hal 1-11

5). Simamora, N, F. (2019). Sifat Dan Tahap-Tahap Dalam Proses Keperawatan. Osf.io

6). Simamora, R. H. (2019). Development of Guidelines for Applying appropriate Patient Identification to Achieve Patient Safety Goal INC2019 12th International Nursing Conference. 2019.10455 - 455 (1 pages) UCI(KEPA) : I410-ECN-0101-2019-512-001224337

7). Simamora. R. H. (2008) The correlation of ward chief's giving direction and command and the performance of on-duty nurses at Jember dr. Subandi general hospital inpatient wards. jurnal Administrasi dan Kebijakan Kesehatan, (https://fkm.unair.ac.id/jurnal-administr)

8). Sugiyati, S. (2014). Hubungan Pengetahuan Perawat Dalam Dokumentasi Keperawatan Dengan Pelaksanaannya Di Rawat Inap RSI Kendal. Prosiding Konferensi Nasional II PPNI 
9). Supratti, Ashriady. (2016). Pendokumentasian Standar Asuhan Keperawatan Di Rumah Sakit Umum Daerah Mamuju, Indonesia. Jurnal Kesehatan Manarang, 2(1).

10). Wirawan, E,A., Dwi, N., Fiki, W. (2013). Hubungan Antara Supervisi Kepala Ruang Dengan Pendokumentasian Asuhan Keperawatan Di Rumah Sakit Umum Daerah Ambarawa. Jurnal Managemen Keperawatan, 1 (1).

11). Wirdah, H., Muhmmad, Y. (2016). Penerapan Asuhan Keperawatan Oleh Perawat Pelaksana di Rumah Sakit Banda Aceh. Jurnal Ilmiah Mahasiswa Fakultas Keperawatan, 1, 1-6.

12). Yanti, R, I., Bambang, E, W. (2013). Hubungan Karakteristik Perawat,Motivasi, Dan Supervisi Dengan Kualitas Dokumentasi Proses Asuhan Keperawatan. Jurnal Managemen Keperawatan, 1 (2). 